\title{
REPRESENTASI MATEMATIS SISWA DALAM PEMECAHAN MASALAH PERBANDINGAN TRIGONOMETRI PADA SEGITIGA SIKU-SIKU DITINJAU DARI KECERDASAN LOGIS MATEMATIS, LINGUISTIK DAN VISUAL SPASIAL
}

\author{
Merlin Hitalessy $^{1 *}$, Wilmintjie Mataheru², Carolina S. Ayal ${ }^{3}$ \\ ${ }^{1}$ Program Studi Magister Matematika, Pascasarjana, Universitas Pattimura \\ Jalan Ir. M. Putuhena, Kampus Unpatti, Poka, Ambon, Indonesia \\ e-mail: ${ }^{1}$ merlinhitalessy@gmail.com;
}

corresponding author*

\begin{abstract}
Abstrak
Salah satu kemampuan yang diperlukan dalam pembelajaran matematika adalah kemampuan memecahkan masalah matematika. Dalam pembelajaran matematika, representasi matematis dibutuhkan siswa dalam proses penyelesaian masalah. Siswa cenderung menggunakan representasi matematis, namun terkadang tidak paham dengan apa yang mereka kerjakan. Secara umum representasi matematis juga sangat berperan dalam peningkatan kompetensi matematika. Selain kemampuan representasi, siswa juga memiliki kecerdasan, antara lain kecerdasan logis matematis, linguistik dan visual spasial. Penelitian ini merupakan penelitian deskriptif kualitatif yang bertujuan untuk mendiskripsikan secara lengkap representasi matematis siswa SMK dalam memecahkan masalah perbandingan trigonometri pada segitiga siku-siku ditinjau dari kecerdasan logis matematis, linguistic dan visual spasial. Tahap penelitian dimulai dengan pemilihan subjek penelitian yang ditentukan berdasarkan gender dan hasil tes kemampuan matematika yang setara. Setelah terpilih subjek kemudian dilanjutkan dengan pemberian tugas pemecahan masalah persamaan kuadrat dan wawancara. Keabsahan data dilakukan dengan menggunakan triangulasi waktu yaitu pemberian tugas pemecahan masalah persamaan kuadrat yang setara pada waktu yang berbeda. Hasil penelitian ini berupa deskripsi matematis dari siswa SMK dalam memecahkan masalah persamaan kuadrat untuk setiap tahap pemecahan masalah menurut tahapan Polya.
\end{abstract}

Kata Kunci: representasi matematis, kecerdasan logis matematis, linguistik, visual spasial

\section{STUDENT'S MATHEMATICAL REPRESENTATION IN SOLVING TRIGONOMETRY COMPARATIVE PROBLEMS IN RIGHT TRIANGLES IN TERMS OF MATHEMATICAL LOGICAL INTELLIGENCE, LINGUISTICS AND VISUAL SPATIAL}

\begin{abstract}
One of the skills needed in learning mathematics is the ability to solve mathematical problems. In solving problems in mathematics learning, mathematical representation is needed by students in the problem solving process. Students tend to use mathematical representations, but sometimes they don't understand what they are doing. In general, mathematical representations also play an important role in improving mathematical competence. Beside the ability of representation, students also have intelligence, including mathematical logical intelligence, linguistics and visual spatial. This research is descriptive with qualitative approach that aimed to describe the complete mathematical representation of vocational high school students in solving a quadratic equation in terms. The research phase begins with the selection of research subjects were determined by gender and math skills test results were similar. Having chosen the subject and the continuation of the problem solving quadratic equations and interviews. The validity of the data using a triangulation of time that is giving the task of solving a quadratic equation are equal at different times. The results of this study as the mathematic description shows that vocational high school students in solving quadratic equations problem according to Polya step problem solving.
\end{abstract}

Keywords: mathematical representations, mathematical logical intelligence, linguistics, visual spatial 


\section{Pendahuluan}

NCTM (dalam Rahmadian, dkk 2019: 287) menyatakan bahwa proses representasi melibatkan penerjemaah masalah atau ide ke dalam bentuk baru. Selanjutnya, NCTM juga menetapkan Lima proses standar matematis yang harus dimiliki oleh siswa, yaitu: kemampuan pemecahan masalah, kemampuan penalaran, kemampuan komunikasi, kemampuan koneksi, dan kemampuan representasi).

Representasi menurut Jones dan Knuth (dalam Mustangin, 2015: 16) adalah model atau bentuk pengganti dari suatu situasi masalah atau aspek dari suatu situasi masalah yang digunakan untuk menentukan solusi. Kaput (dalam Mustangin, 2015: 16) memandang representasi sebagai alat-alat yang digunakan individu untuk mengorganisir dan menjadikan situasi-situasi lebih bermakna. Kartini (2009: 370) menyatakan representasi matematis adalah ungkapan-ungkapan dari ide-ide matematika yang digunakan untuk memperlihatkan hasil kerja dengan cara tertentu sebagai interpretasi dari pikirannya.

Berdasarkan uraian tersebut, kemampuan representasi dan pemecahan masalah termuat pada kemampuan standar menurut Depdiknas dan NCTM. Artinya, dua kemampuan ini penting dikembangkan dan harus dimiliki siswa. NCTM (dalam Dewi,dkk, 2015: 26) menetapkan lima standar proses pembelajaran matematika, yaitu:

a. Kemampuan menggunakan konsep dan keterampilan matematis untuk memecahkan masalah (problem solving);

b. Menyampaikan ide atau gagasan (communication);

c. Memberikan alasan induktif maupun deduktif untuk membuat, mempertahankan, dan mengevaluasi argument (reasoning);

d. Menggunakan pendekatan, keterampilan, alat, dan konsep untuk mendeskripsikan dan menganalisis data (representation);

e. Membuat pengaitan antara ide matematika, membuat model dan mengevaluasi struktur matematika (connections).

Dalam memecahkan masalah, setiap siswa mempunyai cara berbeda untuk mempresentasikan pengetahuannya. Lesh, Post dan Behr (dalam Kartini, 2009: 366) menyatakan representasi eksternal meliputi: representasi objek dunia nyata, representasi konkrit, simbol aritmatika, bahasa lisan dan gambar atau grafik. Dari kelima bentuk representasi, tiga diantaranya berada pada tingkatan yang lebih abstrak atau berada pada level yang lebih tinggi yaitu: representasi simbol aritmetika, bahasa lisan dan gambar atau grafik. .
Menurut Yuhasty \& Evianti (2014: 53), keberhasilan dalam pemecahan masalah yaitu dapat memecahkan permasalahan dengan benar sehingga tidak lagi ada gab atau kesenjangan antara harapan dan kenyataan, antara apa yang diinginkan atau apa yang dituju dengan apa yang terjadi atau faktanya.

Selain kemampuan representasi matematis, ada faktor lain yang dapat membantu siswa memecahkan masalah. Salah satu faktornya yaitu kecerdasan. Menurut Gardner (dalam Yaumi, 2015: 186), dalam diri seseorang terdapat sembilan kecerdasan yaitu kecerdasan linguistik, music, logis matematis, visual spasial, kinestetik, interpersonal dan intrapersonal, natural dan eksistensial. Namun untuk orang-orang tertentu ada suatu kecerdasan yang lebih menonjol dibanding kecerdasan lain.

Kemampuan representasi matematis dipengaruhi oleh kecerdasan linguistik, logis matematis dan visual spasial (Asyrofi \& Junaedi, 2016: 38). Selain itu, kemampuan seseorang menggunakan representasi dipengaruhi oleh format representasi, konsep, umur, serta perbedaan individual. Perbedaan individual ini salah satunya dipengaruhi oleh kecerdasan (Ainsworth, 1999: 136).

\subsection{Representasi Matematis}

Kartini (2009: 369) menyatakan representasi matematis adalah ungkapan-ungkapan atau ide-ide matematika (masalah, pernyataan, definisi, dan lain-lain) yang digunakan untuk memperlihatkan (mengkomunikasikan) hasil kerjanya dengan cara tertentu (cara konvensional) sebagai hasil interpetasi dari pikirannya. NCTM (2000) mengungkapkan representasi matematis bukan hanya suatu produk tetapi juga suatu proses, dalam hal ini representasi berkaitan dengan menangkap konsep matematis atau mengaitkannya ke dalam beberapa bentuk dan bentuk itu sendiri.

NCTM (2014) mengemukakan elemenelemen kunci untuk mengikuti standar proses representasi. Siswa harus terlibat dengan siswa lain dalam semua proses belajar matematika seperti

a. Membuat dan menggunakan representasi untuk mengatur, merekam, dan mengomunikasikan ide-ide matematika;

b. Pilih, terapkan, dan terjemahkan di antara representasi matematis untuk menyelesaikan masalah;

c. Gunakan representasi untuk memodelkan dan menafsirkan fenomena fisik, sosial, dan matematika. 
Menurut Goldin \& Shteingold (dalam Farahhadi dan Wardono, 2019: 606), representasi terdiri dari dua system, yaitu system representasi eksternal dan internal. Representasi Internal adalah semacam tanda atau simbol, karakter, atau objek untuk melambangkan, menggambarkan, mengode, atau mewakili sesuatu selain dirinya sendiri. Bentuk representasi matematis yang akan digunakan dalam penelitian ini merujuk pada bentuk representasi yang dikembangkan oleh Goldin dan Shteingold, yaitu:

a. Notasi formal adalah bentuk representasi yang menyatakan situasi masalah simbol, model matematika, melakukan perhitungan dan manipulasi model matematika.

b. Visual spasial adalah bentuk representasi yang menyatakan situasi masalah melalui garis bilangan, grafik, diagram, tabel atau gambar.

c. Verbal adalah bentuk representasi yang menyatakan situasi masalah melalui kata-kata atau kalimat, baik secara tertulis maupun lisan.

Berdasarkan definisi yang dikemukakan para ahli di atas, dapat disimpulkan bahwa representasi adalah proses menemukan solusi dengan mengungkapkan ide-ide yang dibangun melalui pengalaman sebagai pengganti dari suatu bentuk atau model dari suatu masalah. Sedangkan representasi matematis adalah proses menangkap hubungan dalam suatu bentuk kemudian bentuk tersebut ditampilkan siswa dalam bentuk visual, verbal maupun notasi formal.

\subsection{Pemecahan Masalah}

Secara umum masalah adalah kesenjangan antara harapan dengan kenyataan, antara apa yang diinginkan atau apa yang menjadi tujuan dengan apa yang terjadi atau faktanya. Menurut Lesh dan Zawojewski (dalam Chamberlin, 2009: 7), suatu tugas disebut masalah bagi siswa apabila siswa perlu mengembangkan suatu strategi produktif untuk menyelesaikan tugas tersebut. Hal ini menunjukkan bahwa suatu masalah harus menantang bagi siswa yang akan menyelesaikan masalah tersebut. Meski demikian, terdapat kemungkinan suatu tugas merupakan masalah bagi seorang siswa tetapi tidak bagi siswa yang lain, sehingga masalah bersifat relatif bagi siswa. Terkait dengan hal ini, Chamberlin (2009: 21) menekankan bahwa pemberian tugas perlu disesuaikan dengan tingkat perkembangan siswa.

Dalam proses pemecahan masalah ada langkah-langkah yang harus dilaksanakan. Polya (1973: 5) menjabarkan empat langkah yang harus dilakukan dalam pemecahan suatu masalah, yaitu:

a. Memahami masalah
Beberapa indikator yang menunjukkan bahwa siswa memahami masalah, yaitu:

i. Mengungkapkan unsur-unsur yang diketahui dan tidak diketahui dalam masalah atau menggungkapkan informasiinformasi yang penting dalam masalah.

ii. Menyatakan kembali masalah tersebut secara lebih sederhana.

iii. Mengungkapkan sesuatu yang berhubungan dengan masalah tersebut.

b. Membuat rencana pemecahan masalah.

Indikator yang menunjukkan bahwa siswa membuat rencana pemecahan masalah, yaitu:

i. Menyatakan hubungan antara informasi yang tidak diketahui dengan informasi yang diketahui dalam masalah tersebut.

ii. Merencanakan strategi yang sesuai berdasarkan hubungan yang diperoleh.

iii. Menggunakan teori yang tepat untuk menyelesaikan soal tersebut.

c. Melaksanakan rencana

Indikator yang menunjukkan siswa melaksanakan rencana yaitu:

i. Melaksanakan rencana penyelesaian.

ii. Mengecek setiap langkah yang digunakan.

iii. Mengoreksi atau memperbaiki kesalahan yang dibuat.

Polya (dalam Mink, 2012: 197) juga mengemukakan bahwa melaksanakan rencana berarti menyelesaikan masalah. Instruksi kuat tentang berbagai strategi pemecahan masalah harus disediakan sehingga siswa dapat berhasil menindaklanjuti dengan solusi. Siswa harus bekerja melalui setiap bagian dari masalah, menggunakan strategi yang mereka pilih, sampai mereka menemukan jawaban untuk masalah tersebut.

i. Siswa harus mencatat langkah pemecahan masalah mereka secara terorganisir sehingga mereka dapat melihat pekerjaan mereka dan memutuskan apakah strategi yang mereka pilih akan memberi mereka hasil yang dibutuhkan.

ii. Jika siswa terjebak, mereka dapat meninjau pekerjaan mereka untuk memastikan mereka tidak membuat kesalahan dalam perhitungan mereka. Jika strategi yang dipilih tidak berhasil dengan masalah, siswa harus kembali ke daftar strategi mereka dan memilih pendekatan yang berbeda untuk menyelesaikan masalah.

d. Memeriksa kembali.

Indikator yang menunjukkan bahwa siswa mengevaluasi kembali hasil pekerjaanya, yaitu:

i. Mencocokkan hasil yang diperoleh dengan hal yang ditanyakan. 
ii. Mengintrepetasikan jawaban yang diperoleh.

iii. Mengidentifikasi adakah cara lain untuk mendapatkan penyelesaian masalah.

iv. Mengidentifikasi adakah jawaban atau hasil lain yang memenuhi.

Berdasarkan uraian di atas, pemecahan masalah adalah suatu upaya atau jalan yang dilakukan siswa untuk menyelesaikan atau memecahkan masalah melalui tahap-tahap yang terstruktur. Tahap-tahap pemecahan masalah dalam penelitian ini berpedoman pada tahap pemecahan masalah yang dikemukakan oleh Polya dan telah dibahas pada poin sebelumnya. Hal

Tabel 1. Indikator Representasi Matematis Siswa dalam Pemecahan Masalah

\begin{tabular}{|c|c|}
\hline $\begin{array}{l}\text { Tahapan Pemecahan } \\
\text { Masalah }\end{array}$ & Indikator Representasi Matematis \\
\hline \multirow[t]{6}{*}{ Memahami } & 1. Menyajikan informasi yang diketahui dalam membentuk verbal \\
\hline & 2. Menyajikan informasi yang diketahui dalam bentuk notasi formal \\
\hline & 3. Menyajikan informasi yang diketahui dalam bentuk visual \\
\hline & 4. Menyajikan informasi yang ditanyakan dalam bentuk verbal. \\
\hline & 5. Menyajikan informasi yang ditanyakan dalam bentuk non formal \\
\hline & 6. Menyajikan informasi yang dinyatakan dalam bentuk visual \\
\hline \multirow[t]{7}{*}{ Merencanakan } & $\begin{array}{l}\text { 7. Menyajikan ide-ide yang membantu menentukan hubungan antara yang diketahui } \\
\text { dan dinyatakan dalam bentuk verbal. }\end{array}$ \\
\hline & $\begin{array}{l}\text { 8. Menyajikan ide-ide yang membantu menentukan hubungan antara yang diketahui } \\
\text { dan ditanyakan dalam bentuk notasi formal. }\end{array}$ \\
\hline & $\begin{array}{l}\text { 9. Menyajikan ide-ide yang membantu menentukan hubungan antara yang diketahui } \\
\text { dan ditanyakan dalam bentuk visual }\end{array}$ \\
\hline & 10. Menyajikan hubungan antar bagian seperti memberi tanda dengan simbol tertentu \\
\hline & 11. Menyajikan strategi dalam bentuk verbal \\
\hline & 12. Menyajikam strategi dalam bentuk notasi formal \\
\hline & 13. Menyajikan strategi dalam bentuk visual \\
\hline \multirow[t]{3}{*}{ Melaksanakan } & $\begin{array}{l}\text { 14. Melakukan perhitungan bilangan, membuat model matematika yang sesuai } \\
\text { dengan informasi pada soal }\end{array}$ \\
\hline & 15. Menyajikan hubungan antar bagian seperti memberi tanda dengan symbol tertentu \\
\hline & 16. Menginterpetasikan hasil penyelesaian yang diperoleh secara verbal \\
\hline Memeriksa & $\begin{array}{l}\text { 17. Memeriksa kembali penyelesaian, mengungkapkan benar tidaknya langkah } \\
\text { penyelesaian melalui notasi formal. }\end{array}$ \\
\hline
\end{tabular}

\subsection{Kecerdasan}

Menurut Asyrofi \& Junaedi (2016: 38) faktor lain dalam meningkatkan kemampuan representasi matematis adalah tingkat kecerdasan. Kemampuan representasi matematis dipengaruhi oleh kecerdasan linguistik, logis mathematis, dan visual spatial. Ketiga kecerdasan ini erat kaitannya dan memiliki pengaruh terhadap representasi matematis siswa. Dengan demikian, dalam penelitian ini, akan dibahas mengenai tiga tipe kecerdasan yaitu: (1) kecerdasan linguistik, (2) kecerdasan logis matematis, dan (3) kecerdasan visual spasial. Berikut ini adalah penjelasan dari kecerdasan majemuk yang dimaksud.

Sejalan dengan hal tersebut, Gardner (dalam Yaumi, 2015: 186) juga mengemukakan bahwa kecerdasan yang dikembangkan dalam tersebut dikarenakan tahap-tahap pemecahan masalah Polya cukup sederhana dan terperinci dengan baik.

\subsection{Representasi Dalam Pemecahan Masalah}

Untuk mengetahui bagaimana proses representasi siswa dalam menyelesaikan masalah, dalam penelitian ini menggunakan indikator pemecahan masalah yang dikemukakan oleh Polya (1973) dan indikator representasi matematatis oleh Goldin \& Steingold. Indikator representasi matematis dalam pemecahan masalah yang digunakan pada penelitian ini terdapat pada Tabel 1. 
dengan orang lain. Mampu menggunakan kata-kata untuk mengungkapkan perbedaan ketika dua atau tiga benda dibandingkan. Mereka juga suka mengajukan banyak pertanyaan, suka bicara, memiliki banyak kosa kata, suka membaca dan menulis, memahami fungsi bahasa, dapat berbicara tentang ketrampilan bahasa. Dengan demikian kecerdasan linguistik adalah kemampuan untuk memahami bahasa secara lisan ataupun tulisan, serta menggunakan bahasa tersebut untuk mengekspresikan diri baik secara lisan maupun tulisan.

Amstrong (dalam Irvaniyah dan Akbar, 2014: 145) mengemukakan kecerdasan logis matematis adalah kemampuan menggunakan angka secara efektif dengan alasan yang baik. Gardner (dalam Irvaniyah dan Akbar, 2014: 141) menjelaskan bahwa Seseorang dengan kecerdasan logis-matematis (logika matematika) menonjol, dapat mengkonstruksikan sebuah solusi sebelum hal itu diartikulasikan. Gardner mengategorikan kecerdasan logika-matematika seseorang kerapkali tak hanya mengandalkan keterampilan seseorang menganalisis, melainkan juga sebuah kemampuan intuitif menuju sebuah jawaban atau solusi. Dengan demikian kecerdasan logis matematis adalah kemampuan seseorang dalam berpikir secara deduktif induktif, kemampuan berpikir menurut aturan, memahami dan menganalisa masalah untuk memecahkannya.

Beberapa pendapat mengenai kecerdasan visual spasial dikemukaan oleh peneliti terdahulu salah satunya adalah Amstrong (2009: 13). Menurutnya kecerdasan visual spasial adalah kemampuan untuk menangkap dunia ruang-visual secara tepat seperti dimiliki para pemburu, pramuka atau pemandu dan melakukan transformasi berdasarkan persepsi tersebut seperti dekorator, interior, arsitek atau penemu. Menurut Rosidah (2014: 300), kecerdasan visual spasial adalah kapasitas untuk mengenali dan melakukan penggambaran atas objek atau pola yang diterima otak. Dengan demikian kecerdasan visual spasial adalah kemampuan melihat dan mengamati objek, dan melakukan representasi yang akurat atas objek yang diterima otak. Siswa dengan kecerdasan ini akan memiliki daya khayal yang tinggi atau suka berimajinasi tentang sesuatu hal, sehingga ia dapat dikatakan imajinatif dan kreatif.

\section{Metode Penelitian}

Penelitian ini adalah penelitian deskriptifkualitatif, artinya mendiskripsikan atau menggambarkan kejadian-kejadian yang menjadi pusat perhatian (representasi matematis terhadap pemecahan masalah yang ditinjau dari kecerdasan majemuk siswa) secara kualitatif.

Sumber data dalam penelitian ini adalah seluruh siswa kelas X SMK Negeri 1 Ambon Tahun Pelajaran 2019/2020 yang terdiri dari empat program studi keahlian, yaitu: Program Studi Keahlian Akuntansi dan Keuangan, Administrasi Perkantoran, Tata Niaga dan Usaha Perjalanan Wisata. Selanjutnya diambil 3 subjek berdasarkan kecerdasan linguistic, visual spasial, dan logis matematis.

Instrumen yang digunakan dalam menentukan subjek penelitian adalah angket kecerdasan majemuk yang diadopsi dari Winarto (2010: 5). Tugas pemecahan masalah yang digunakan pada penelitian ini untuk mengetahui representasi matematis subjek penelitian dalam memecahkan masalah matematika baik secara lisan maupun tulisan.

Teknik analisa data yang akan digunakan dalam penelitian ini menggunakan model analisis data Miles, et al (2014: 30), model ini terdiri atas tiga tahapan, sebagai berikut.

a. Tahap kondensasi data

Kondensasi data merujuk pada proses memilih, memfokuskan, menyederhanakan, mengabstrakan, dan/atau mentransformasikan (mengubah) data yang diperoleh selama penelitian berlangsung, baik dari catatan lapangan, transkrip wawancara, dokumen data empiris lainnya. Tujuan utama kondensasi yaitu penguatan data. Pada model sebelumnya kondensasi dikenal dengan istilah reduksi yaitu penguatan data. Pada model sebelumnya kondensasi dikenal dengan istilah reduksi yaitu pengurangan atau membuang data yang berarti menghilangkan sesuatu yang diperoleh dari proses pengumpulan. Sedangkan, pada kondensasi, data tidak dibuang akan tetapi digabungkan dan dirangkum dengan data yang lain.

Kondensasi data dalam penelitian ini meliputi: mempertajamkan data, menggolongkan data, memfokuskan data, menyisikan data, merangkum data, membuat kode, maupun kategori. Data yang akan dikondensasi yaitu data hasil angket kecerdasan majemuk dan wawancara berbasis tugas.

b. Penyajian data

Secara umum, penyajian data adalah proses penyusunan informasi yang diatur dengan lebih sederhana, agar peneliti dapat melihat apa yang sedang terjadi, sehingga mempermudah penarikan kesimpulan yang tepat. Data yang telah dikondensasi kemudian 
akan disajikan dalam bentuk uraian singkat, bagan, grafik, hubungan antar kategori, flowchart dan sejenisnya. Dalam penelitian ini data yang disajikan berupa deskripsi tentang representasi matematis siswa dalam pemecahan masalah perbandingan trigonometri pada segitiga siku-siku ditinjau dari kecerdasan majemuk.

c. Penarikan kesimpulan dan verifikasi

Langkah terakhir dalam teknik analisis data adalah penarikan kesimpulan dan verifikasi. Penarikan kesimpulan yaitu memberikan interpetasi terhadap hasil penyajian data. Kesimpulan diperoleh dari membandingkan kesesuaian antara pernyataan subjek penelitian dengan rumusan pertanyaan penelitian. Menurut Miles, et al (2014: 33) menyatakan bahwa penarikan kesimpulan sebenarnya dimulai sejak proses kendensasi data, tapi kesimpulan tersebut masih bersifat terbuka, atau ragu-ragu. Oleh karena itu perlu diverifikasi (diuji) keabsahannya. Verifikasi dilakukan terus-menerus selama proses penelitian, sampai pengumpulan data benarbenar selesai, sehingga kesimpulan akhir bisa dipertanggungjawabkan dan terjamin keabsahannya. Penarikan kesimpulan dalam penelitian ini bertujuan untuk mendiskripsikan representasi siswa dalam pemecahan masalah perbandingan trigonometri pada segitiga sikusiku.

Selanjutnya, Miles et al (2014: 299) menyatakan triangulasi adalah suatu teknik untuk memeriksa keabsahan data dengan memanfaatkan suatu teknik untuk memeriksa keabsahan data dengan memanfaatkan sesuatu di luar untuk keperluan pengecekan atau sebagai pembanding terhadap data. Menurut Wijaya (2019: 95), peneliti dapat mengecek konsistensi, kedalaman dan ketepatan atau kebenaran suatu data dengan melakukan triangulasi waktu. Menguji kredibilitas data dengan triangulasi waktu dilakukan dengan cara mengumpulkan data pada waktu yang berbeda.

Triangulasi dalam penelitian ini adalah triangulasi waktu, yaitu membandingkan data yang diperoleh dari hasil kerja subjek dengan hasil wawancara yang dilaksanakan pada waktu yang berbeda. Selanjutnya, data yang abasah dianalisis dan kemudian dideskripsikan sesuai dengan kecerdasan masing-masing subjek. Analisis dan deskrikpsi dilakukan terhadap representasi matematisnya dalam pemecahan masalah perbandingan trigonometri pada segitiga siku-siku.

\section{Hasil dan Pembahasan}

Pada tahap pelaksanaan, subjek dengan kecerdasan linguistik, visual spasial, dan logis matematis diberikan tugas pemecahan masalah. Berikut ini adalah deskripsi Representasi Matematis subjek dalam pemecahan perbandingan trigonometri pada segitiga siku-siku.

\subsection{Subjek Dengan Kecerdasan Logis Matematis}

Berikut ini adalah hasil kerja tugas pemecahan masalah perbandingan trigonometri subjek DRC dengan kecerdasan logis matematis.

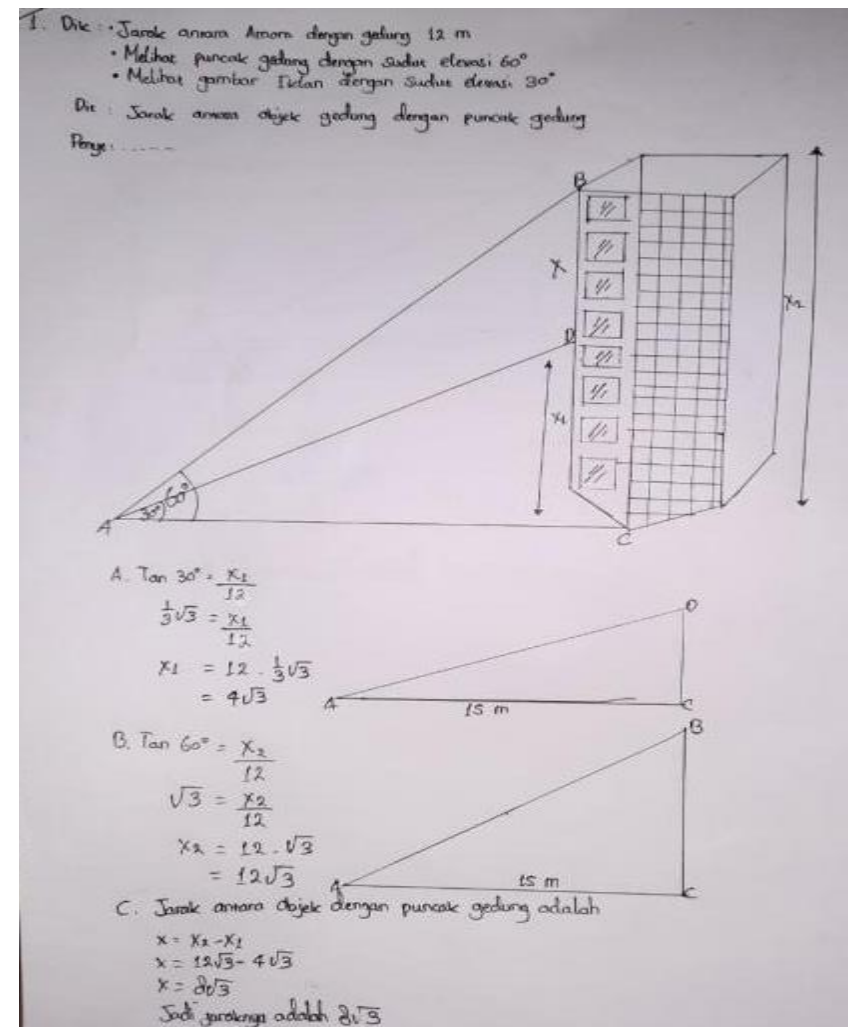

Gambar 1. Pekerjaan Subjek DRC

Representasi matematis subjek DC dalam pemecahan masalah perbandingan trigonometri sesuai dengan tahap-tahap pemecahan masalah, sebagai berikut:

a. Tahap Memahami

Berdasarkan lembar jawaban dan wawancara di atas, terlihat bahwa DRC telah memenuhi indikator memahami.

i. Menyajikan informasi yang diketahui dalam bentuk representasi verbal yaitu menyajikan dengan tulisan lisan maupun tulisan informasi yang diketahui seperti sudut elevasi yang terbentuk pada pandangan Amora ke puncak gedung, dan iklan pada gedung, serta jarak Amora dengan gedung.

ii. Menyajikan informasi yang diketahui dalam bentuk representasi notasi formal seperti simbol-simbol. AB untuk jarak 
pandang Amora dengan puncak gedung, AC untuk jarak Amora dengan gedung, AD untuk jarak pandang Amora ke iklan pada gedung. Sudut $A=60^{\circ}$ untuk segitiga $A B C$ dan sudut $A=30$ pada segitiga ADC.

iii. Menyajikan informasi yang diketahui dalam bentuk visual menggambarkan ilustrasi gambar dan menyajikannya dalam bentuk segitiga.

iv. Menyajikan informasi yang ditanyakan dalam bentuk representasi verbal seperti tulisan lisan maupun tulisan.

v. Menyajikan informasi yang ditanyakan dalam bentuk notasi formal yaitu BD untuk jarak antara puncak gedung dan iklan pada gedung.

vi. Menyajikan informasi yang ditanyakan dalam bentuk visual yaitu pada gambar ilustrasi cerita dan segitiga yang dibuat, dapat menunjukan jarak antara puncak gedung dan iklan pada gedung BD pada gambar yang telah dibuat.

b. Tahap Merencanakan

Berdasarkan transkrip wawancara dan hasil kerja Tugas pemecahan masalah, terlihat DRC telah memenihi indakator merencanakan.

i. Menyajikan ide-ide yang membanitu menenitukan hubungan antara yang diketahui dan ditanyakan dalam bentuk representasi verbal seperti menyatakan dengan tulisan yaitu informasi yang disajikan pada tahap memahami tadi dikaitkan bahwa telah diketahui salah satu sudut dan sisi samping dalam segitiga siku-siku. Maka DRC mengemukakan untuk mendapatkan sisi depan yaitu tinggi gedung dari puncak dan dari iklan ke titik gedung yang sejajar dengan pandangan Amora dapat menggunakan perbandingan tangen.

ii. Menyajikan hubungan antar bagian dengan simbol tersebut seperti menggambrkan anak panak untuk menandai tinggi gedung dari puncak ke titik pada gedung yang sejajar dengan pandangan Amora, dan garis anak panak yang lain untuk tinggi dari iklan pada gedung sampai pada batas gedung yang sejajar dengan pandangan Amora.

iii. Menjelaskan strategi pemecahan masalah seperti menjelaskan langkah-langkah untuk menenitukan penyelesaian soal, yang pertama menenitukan sisi depan segitiga dengan tangen $30^{\circ}$ dan tangen $60^{\circ}$. kemudian hasil akhir didapat dari mengurangi nilai tinggi gedung dari puncak dan tinggi iklan sampai ke titik pada gedung yang sejajar dengan pandangan Amora.

iv. Menyajikan strategi dalam bentuk representasi notasi formal seperti menenitukan nilai seperti menyatakan tangen $30^{\circ}=\frac{x_{1}}{12}, \quad$ tangen $60^{\circ}=\frac{x_{2}}{12}$ dan $x=x_{2}-x_{1}$.

v. Menyajikan strategi dalam bentuk visual seperti mampu menjelaskan strategi pada gambar segitiga yang telah dibuat. Menunjukan bagian sisi samping yang diketahui dan bagian sisi depan yang akan dicari dengan menggunakan informasi diperoleh pada langkah sebelumnya.

c. Tahap Melaksanakan

Berdasarkan lembaran jawaban dan transkrip wawancara DRC memenuhi indikator pemecahan masalah tahap melaksanakan.

i. Melaksanakan rencana pemecahan dengan melakukan perhitungan bilangan sesuai dengan informasi pada soal dan ide serta strategi yang telah dikemukakan berupa langkah demi langkah. Seperti melakukan perhitungan menggunakan perbandingan tangen $30^{\circ}$ untuk menenitukan nilai $x_{1}$ yang merupakan jarak antara iklan dan batas gedung. Kemudian menghitung nilai $x_{2}$ dengan menggunakan perbandingan tangen $60^{\circ} \cdot x_{2}$ yaitu jarak antara puncak gedung dan batas gedung. Selanjutnya, untuk menenitukan nilai akhir DRC melakukan operasi pengurangan $x_{2}-x_{1}$.

ii. Menginterpretasikan hasil penyelesaian yang diperoleh secara verbal seperti menyatakan penyelesaian dengan tulisan, kalimat yang tepat serta memberikan alasan pada langkah-langkah penyelesaian.

d. Tahap Memeriksa

Berdasarkan lembar jawaban dan transkrip nilai di atas, terlihat bahwa VP telah memenuhi indikator memeriksa kembali penyelesaian, meneliti hasil operasi bilangan yang dilakukan setiap langkahnya, serta menenitukan benar tidaknya nilai perbandingan tangen melalui representasi notasi formal dan secara lisan dapat menjelaskannya kembali.

\subsection{Subjek Dengan Kecerdasan Linguistik}

Berikut ini adalah hasil kerja tugas pemecahan masalah perbandingan trigonometri subjek DC dengan kecerdasan linguistik. 


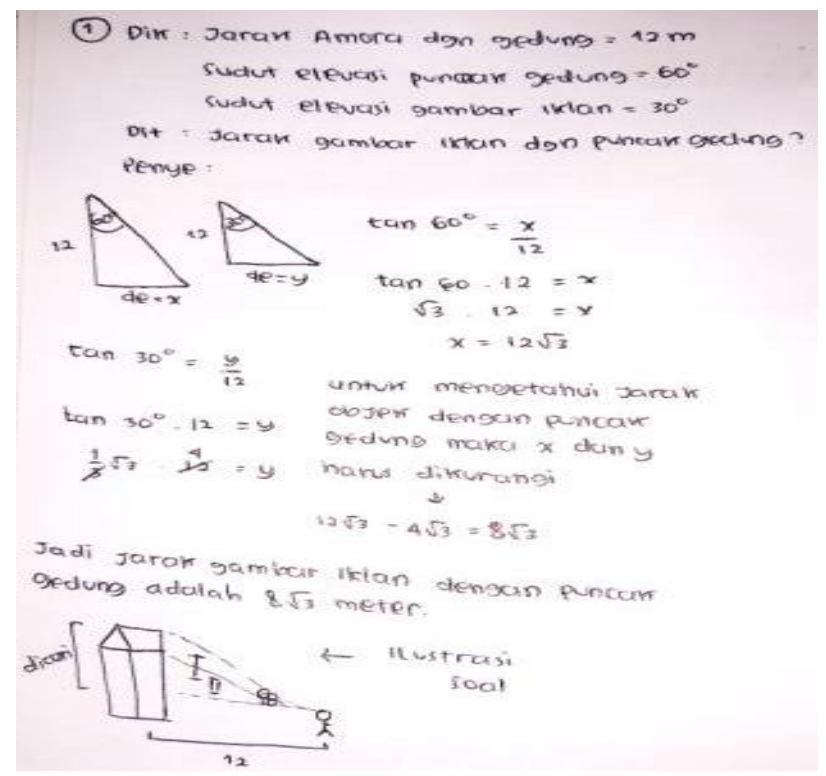

Gambar 2. Pekerjaan Subjek MP

Representasi matematis subjek DC dalam pemecahan masalah perbandingan trigonometri sesuai dengan tahap-tahap pemecahan masalah, sebagai berikut:

a. Tahap Memahami

Berdasarkan lembar jawaban dan wawancara yang dilakukan, terlihat bahwa MP telah memenuhi indikator memahami.

i. Menyajikan informasi yang diketahui dalam bentuk representasi verbal yaitu menyajikan dengan tulisan lisan maupun tulisan informasi yang diketahui seperti sudut elevasi yang terbentuk pada pandangan Amora ke puncak gedung, dan iklan pada gedung, serta jarak Amora dengan gedung.

ii. Menyajikan informasi yang diketahui dalam bentuk visual menggambarkan ilustrasi gambar, kemudian menyajikan dua segitiga yang dibentuk dari gambar ilustrasi yang dibuat yaitu segitiga besar (I) dan segitiga kecil (II).

iii. Menyajikan informasi yang ditanyakan dalam bentuk representasi verbal seperti tulisan lisan maupun tulisan yaitu jarak antara puncak gedung dan iklan pada gedung.

iv. Menyajikan informasi yang ditanyakan dalam bentuk notasi formal yaitu de $=x$ untuk jarak antara puncak gedung dengan batas gedung yang sejajar dengan pandangan Amora. $\mathrm{de}=y$ untuk jarak iklan pada gedung dengan batas gedung sejajar dengan pandangan Amora. MP memberikan notasi de untuk sisi depan.

v. Menyajikan informasi yang ditanyakan dalam bentuk visual yaitu pada gambar ilustrasi cerita dan segitiga yang dibuat, dapat menunjukan jarak antara puncak gedung dan iklan pada gedung dengan memberikan tangenda pada gambar yang telah dibuat. Selanjutnya pada gambar tersebut MP menuliskan kata dicari, yang menunjukan informasi yang ditanyakan.

b. Tahap Merencanakan

Berdasarkan lembar jawaban dan transkrip wawancara di atas, terlihat bahwa MP telah memenuhi indikator pada tahap merencanakan.

i. Menyajikan ide yang membanitu menghubungkan antara informasi yang diketahui dan ditanyakan dalam bentuk representasi verbal. Hal tersebut seperti menyatakan menggunakan tangen untuk mencari sisi depan segitiga yang digambarkan pada proses memahami. Sisi depan antara lain untuk segitiga besar dan kecil, yang dijabarkan dari gambar ilustrasi yang dibuat.

ii. Menyajikan strategi dalam bentuk representasi verbal seperti menjelaskan secara lisan maupun dengan tulisan strategi pemecahan masalah seperti tahap pertama menenitukan nilai $x$ dan $y$, dan untuk mendapatkan hasil akhir dengan mengurangi nilai $x$ dan $y$.

iii. Menyajikan strategi pemecahan masalah dalam bentuk notasi formal seperti menyatakan perbandingan tangen tangen $30^{\circ}=\frac{x}{12}$ dan tangen $60^{\circ}=\frac{y}{12} \cdot x$ menyatakan sisi depan segitiga kecil yang merupakan jarak antara iklan dengan batas gedung yang sejajar dengan pandangan Amora. Selanjutnya, $y$ merupakan jarak antara gedung dengan batas gedung yang sejajar dengan pandangan Amora.

iv. Menyajikan strategi dalam bentuk notasi visual yaitu dengan menggunakan gambar segitiga yang diangkat dari ilustrasi gambar yang dibuat untuk menjelaskan strategi yang dipakai untuk menyelesaikan soal.

c. Tahap Melaksanakan

Berdasarkan lembaran jawaban dan transkrip wawancara di atas, terlihat bahwa MP telah memenuhi indikator melaksanakan.

i. Melaksanakan rencana pemecahan masalah dengan menggunakan representasi notasi formal seperti menggunakan perbandingan tangen dan melakukan perhitungan bilangan.

ii. Menyajikan hubungan antar bagian seperti menghubungkan gambar ilustrasi dengan dan membuat garis putus-putus pada jarak 
pandang Amora ke puncak gedung dan iklan pada gedung sehingga terlihat bahwa ada bentuk segitiga siku-siku pada gambar ilustrasi. Pemberian simbol seperti ini memudahkan MP untuk menenitukan jarak puncak gedung dengan batas gedung yang sejajar dengan pandangan Amora dan jarak iklan dengan batas gedung dengan menggunakan perbandingan tangen.

iii. Menginterpretasikan hasil penyelesaian yang diperoleh secara verbal seperti menyatakan penyelesaian dengan tulisan, kalimat yang tepat serta memberikan alasan pada langkah-langkah penyelesaian yang ditunjukan pada transkrip wawancara (MP13), (MP14), (MP15), (MP17).

d. Tahap memeriksa

Berdasarkan lembar jawaban dan transkrip wawancara di atas, terlihat bahwa MP telah memenuhi indikator memeriksa kembali penyelesaian, mengungkapkan benar tidaknya langkah-langkah penyelesaian, menenitukan benar tidaknya nilai perbandingan tangen melalui representasi notasi formal seperti menghitung kembali operasi bilangan yang dilakukan pada proses penyelesaian.

\subsection{Subjek Dengan Kecerdasan Visual Spasial}

Berikut ini adalah hasil kerja tugas pemecahan masalah perbandingan trigonometri subjek DRC dengan kecerdasan logis matematis.

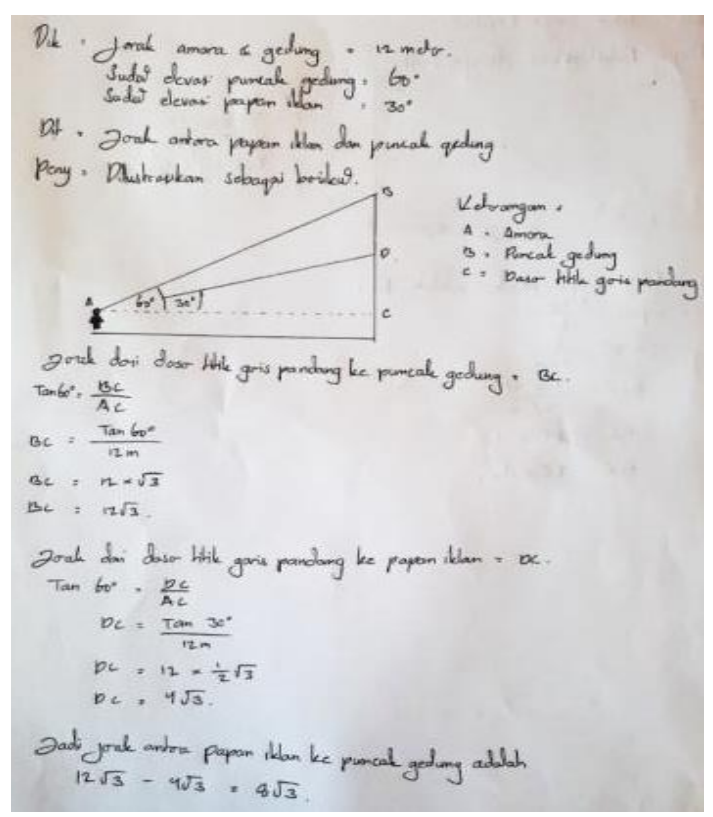

Gambar 3. Pekerjaan Subjek VP

Representasi matematis subjek DC dalam pemecahan masalah perbandingan trigonometri sesuai dengan tahap-tahap pemecahan masalah, sebagai berikut:

a. Tahap Memahami
Berdasarkan lembar jawaban dan wawancara di atas, terlihat bahwa VP telah memenuhi indikator memahami.

i. Menyajikan informasi yang diketahui dalam bentuk representasi verbal yaitu menyajikan dengan tulisan lisan maupun tulisan informasi yang diketahui seperti sudut elevasi yang terbentuk pada pandangan Amora ke puncak gedung, dan iklan pada gedung, serta jarak Amora dengan gedung.

ii. Menyajikan informasi yang diketahui dalam bentuk notasi formal, seperti menggunakan abjad A, B, C, dan D untuk mewakili letak Amora, puncak gedung, iklan pada gedung dan batas gedung yang sejajar dengan pandangan Amora.

iii. Menyajikan informasi yang diketahui dalam bentuk visual menggambarkan ilustrasi gambar, dan gambar segitiga yang sesuai dengan ilustrasi gambar yang dibuat tentag informasi dari soal.

iv. Menyajikan informasi yang ditanyakan dalam bentuk representasi verbal seperti tulisan lisan maupun tulisan yaitu jarak antara puncak gedung dan iklan pada gedung.

v. Menyajikan informasi yang ditanyakan dalam bentuk notasi formal yaitu BD untuk jarak antara puncak gedung dengan batas gedung yang sejajar dengan pandangan Amora dan y untuk jarak iklan pada gedung dengan batas gedung sejajar dengan pandangan Amora.

vi. Menyajikan informasi yang ditanyakan dalam bentuk visual yaitu pada gambar ilustrasi cerita, VP dapat menunjukan jarak antara puncak gedung dan iklan pada gedung dengan memberikan tangenda anak panak gambar yang telah dibuat dan menuliskan tangenda tangenya pada jarak BD yang menunjukan yang ditangenya dari soal tersebut.

b. Tahap Merencanakan

Berdasarkan lembar jawaban dan transkrip wawancara di atas, terlihat bahwa VP telah memenuhi indikator pada tahap merencanakan.

i. Menyajikan ide yang membanitu menghubungkan antara informasi yang diketahui dan ditanyakan dalam bentuk representasi verbal seperti menyatakan menggunakan tangen untuk mencari sisi depan segitiga yang digambarkan pada proses memahami. Sisi depan menunjukan jarak antara puncak gedung dan batas 
gedung, jarak antara iklan pada gedung dan batas gedung.

ii. Menyajikan ide yang telah dikemukakan secara lisan dan tulisan dalam bentuk notasi formal seperti perbandingan tangen sisi depan berbanding sisi miring adalah tangen $60^{\circ}=\frac{B C}{A D}$ dan tangen $30^{\circ}=\frac{C D}{A D}$.

iii. Menyajikan ide dalam bentuk visual seperti menyajikan masalah dalam bentuk ilustrasi gambar yang dapat membanitu memberikan informasi dan juga dapat dipakai untuk menemukan ide dalam menyelesaikan masalah.

iv. Menyajikan strategi dalam bentuk representasi verbal seperti menjelaskan secara lisan maupun dengan tulisan strategi pemecahan masalah seperti tahap pertama menenitukan nilai $\mathrm{BD}$ dan $\mathrm{CD}$, dan untuk menenitukan jarak puncak gedung dan iklan BD dengan mengurangi $\mathrm{BD}$ dan $\mathrm{CD}$.

v. Menyajikan strategi pemecahan masalah dalam bentuk notasi formal seperti menyajikan langkah-langkah untuk menyelesaikan masalah dalam bentuk notasi formal. Langkah pertama menenitukan panjang $\mathrm{BC}$ dengan menggunakan tangen $60^{\circ}=\frac{B C}{A D}$, selanjutnya menenitukan nilai $\mathrm{CD}$ dengan tangen $30^{\circ}=\frac{C D}{A D}$. Setelah menenitukan nilai $\mathrm{BC}$ dan $\mathrm{CD}$, MP menenitukan nilai BD yaitu jarak antara puncak gedung dan iklan.

vi. Menyajikan strategi dalam bentuk notasi visual yaitu dengan menggunakan gambar segitiga yang diangkat dari ilustrasi gambar yang dibuat untuk menjelaskan strategi yang dipakai untuk menyelesaikan soal.

c. Tahap Melaksanakan

Berdasarkan lembaran jawaban dan transkrip wawancara di atas, terlihat bahwa VP telah memenuhi indikator melaksanakan.

i. Melaksanakan rencana pemecahan masalah dengan menggunakan representasi notasi formal seperti menggunakan perbandingan tangen dan melakukan perhitungan bilangan.

ii. Menginterpretasikan hasil penyelesaian yang diperoleh secara verbal seperti menyatakan penyelesaian dengan tulisan, kalimat yang tepat serta memberikan alasan pada langkah-langkah penyelesaian.

\section{d. Tahap Memeriksa}

Berdasarkan lembar jawaban dan transkrip wawancara di atas, terlihat bahwa VP telah memenuhi indikator memeriksa kembali penyelesaian dan menghitung kembali, mengungkapkan benar tidaknya langkahlangkah penyelesaian, menenitukan benar tidaknya nilai perbandingan tangen melalui representasi notasi formal seperti menghitung kembali operasi bilangan yang dilakukan pada proses penyelesaian.

\subsection{Proses Representasi Matematis Subjek Dengan Kecerdasan Logis Matematis (DRC) Dalam Menyelesaikan Masalah Perbandingan Trigonometri Dalam Segitiga Siku-siku.}

a. Tahap Memahami

Pada tahap memahami, subjek menyajikan informasi yang diketahui dalam bentuk representasi verbal, notasi formal dan visual spasial. Representasi verbal disajikan berupa mengungkapkan secara lisan maupun tulisan informasi seperti sudut elevasi yang dibentuk pada saat Amora memandang puncak gedung dan iklan pada gedung, jarak antara Amora dan gedung. Selanjutnya, representasi notasi formal berupa menyatakan AC untuk jarak Amora dengan gedung, $x_{1}=C D$ untuk jarak iklan dengan batas gedung, $x_{2}=B C$ untuk jarak puncak gedung dengan batas gedung, dan $x=B D$ untuk informasi yang ditanyakan yaitu jarak antara puncak gedung dengan iklan, $\mathrm{BC}$ untuk prediksi lebar sungai.

Representasi visual yang ditampilkan subjek dengan menggambarkan ilustrasi soal, dengan menggambarkan posisi Amora dan gedung, dan menarik garis ke titik puncak gedung dan iklan pada gedung. Menggambarkan ilustrasi soal dengan menempatkan A, B, C dengan posisi sesuai dengan informasi pada soal, sehingga dapat menampilkan informasi yang diketahui dan ditanyakan pada soal.

Dari pembahasan di atas terlihat bahwa subjek menyajikan informasi-informasi yang terdapat pada soal, hal ini sesuai dengan yang dikemukakan Polya (1973: 5) pada tahap memahami yaitu siswa juga harus bisa menunjukan bagian utama dari masalah diketahui, data dan kondisinya.

Pada tahap memahami ini, subjek menggunakan ketiga representasi secara bersamaan dalam menyajikan informasi yang diketahui maupun ditanyakan dari soal. Subjek menggunakan representasi visual untuk membantu menyajikan informasi dari masalah matematika yang diselesaikan. Hal ini sesuai dengan yang dikemukakan oleh Polya (1973) jika ada bentuk yang terhubung dengan masalah, siswa harus 
menggambar bentuk dan menunjukan yang tidak diketahui dari datanya.

\section{b. Tahap Merencanakan}

Pada tahap merencanakan, subjek menyajikan ide yang membanitu menenitukan hubungan antara yang diketahui dan ditanyakan dalam bentuk representasi verbal, notasi formal dan visual. Menyajikan ide dalam bentuk visual dengan menggambarkan ilustrasi soal sehingga membanitu untuk menemukan strategi apa yang dipakai untuk menyelesaikan soal. Menyajikan strategi dengan menggunakan ilustrasi gambar untuk membuat dua segitiga yang lain untuk memudahkan dalam menyelesaikan soal. Menjelaskan secara lisan maupun tulisan alasan penggunaan perbandingan tangen berdasarkan informasi yang diketahui dan ditanyakan. Menyatakan ide dan strategi yang telah dikemukakan dalam bentuk notasi formal seperti menyajikan strategi pemecahan masalah dalam bentuk representasi formal untuk mencari solusi dari soal seperti menenitukan nilai tangen $30^{\circ}=$ $\frac{x_{1}}{12}$ untuk memperoleh nilai $x_{1}$, tangen $60^{\circ}=\frac{x_{2}}{12}$ untuk memperoleh nilai $x_{2}$ dan untuk memperoleh jarak antara puncak gedung dan iklan menggunakan $x=x_{2}-x_{1}$.

Berdasarkan pembahasan di atas, terlihat bahwa subjek menyajikan ide-ide yang menyajikan hubungan informasi yang diketahui dan ditanyakan, sesuai dengan pendapat Polya (1973) bahwa hal yang penting dalam pemecahan masalah adalah memikirkan gagasan tentangen sebuah rencana.

Pada bagian lain subjek menyajikan hubungan antar bagian dengan simbol tertentu seperti tangenda anak panak untuk menunjukan bagian-bagian tertentu seperti untuk menunjukan jarak antara puncak gedung dan iklan, puncak gedung dan batas gedung. Hal ini sesuai dengan pendapat Polya (1973) sebagai progres kerja, dapat menambahkan elemen baru ke informasi semula. Sebuah elemen yang diperkenalkan dengan harapan bahwa solusi ini akan disebut elemen tambahan.

\section{c. Tahap Melaksanakan}

Pada tahap melaksanakan, subjek melaksanakan pemecahan masalah dengan menggunakan representasi verbal dan notasi formal. Representasi notasi formal seperti menggunakan perbandingan tangen dan melakukan perhitungan bilangan untuk mencari solusi dari soal. Selanjutnya subjek menggunakan representasi verbal untuk Menginterpretasikan hasil penyelesaian, dan menyatakan kesimpulan jawaban akhir.
Hal tersebut sesuai dengan yang di kemukakan oleh Polya (1973) bahwa pada tahapan ini dapatkah anda melihat dengan jelas bahwa langkah itu benar? Dapatkah anda membuktikan bahwa itu benar? Pada bagian ini rencana yang telah dibuat, akan dilaksanakan. Dengan demikian pada tahapan ini subjek melakukan tahapan sesuai dengan yang dikemukanan oleh Polya.

\section{d. Tahap Memeriksa}

Pada tahap memeriksa, subjek memeriksa kembali penyelesaian hanya secara verbal dengan menunjukan kembali proses penyelesaian untuk memastikan benar tidaknya jawaban dari hasil operasi yang dilakukan di setiap langkah penyelesaian. Pemeriksaan dilakukan secara verbal karena perhitungan bilangan yang dilakukan tidak melibatkan bilangan yang rumit, sehingga tidak dilakukan pengecekan kembali seperti melakukan perkalian bersusun.

Berdasarkan pendapat yang dikemukakan oleh Polya (1973) bahwa pada tahapan ini bisakah anda memeriksa hasilnya? Bisakah anda memeriksa argumennya? Bisakah anda menurunkan hasilnya secara berbeda? Bisakah kamu melihatnya sekilas? Dapatkah anda menggunakan hasilnya, atau metode, untuk beberapa masalah lainnya. Selain itu Polya (1973) menyatakan bahwa untuk melihat ke belakang adalah memeriksa solusi yang diperoleh dari menyaring masalah menggunakan strategi yang dipilih. Langkah dalam proses penyelesaian masalah ini mendorong siswa untuk merefleksikan strategi yang mereka pilih dan membuat generalisasi yang dapat diterapkan untuk masalah di masa depan.

\subsection{Proses Representasi Matematis Subjek Dengan Kecerdasan Linguistik (MP) Dalam Menyelesaikan Masalah Perbandingan Trigonometri Dalam Segitiga Siku-siku.}

a. Tahap Memahami

Pada tahap memahami, subjek menyajikan informasi yang diketahui dalam bentuk representasi verbal yaitu menyajikan dengan tulisan lisan maupun tulisan informasi yang diketahui seperti sudut elevasi yang terbentuk pada pandangan Amora ke puncak gedung, dan iklan pada gedung, serta jarak Amora dengan gedung, dan yang ditanyakan menenitukan jarak puncak gedung dengan iklan pada gedung. Menyajikan informasi yang diketahui dan ditanyakan dalam bentuk visual dengan menggambarkan ilustrasi gambar dan menyajikannya dalam dua bentuk segitiga.

MP menyajikan informasi yang ditanyakan dalam bentuk notasi formal Pada soal nomor 1, 
yaitu $x$ untuk jarak antara puncak gedung dengan batas gedung yang sejajar dengan pandangan Amora. Menyatakan $y$ untuk jarak iklan pada gedung dengan batas gedung sejajar dengan pandangan Amora.

Dari pembahasan di atas terlihat bahwa subjek menyajikan informasi-informasi yang terdapat pada soal, hal ini sesuai dengan yang dikemukakan Polya (1973) pada tahap memahami yaitu siswa juga harus bisa menunjukan bagian utama dari masalah diketahui, data dan kondisinya.

Pada tahap memahami, subjek cenderung menggunakan ketiga representasi verbal, notasi formal dan visual dalam menyajikan informasi yang diketahui maupun ditanyakan dari soal. Subjek menggunakan representasi visual untuk membantu menyajikan informasi dari masalah matematika yang diselesaikan. Hal ini sesuai dengan yang dikemukakan oleh Polya (1973) jika ada bentuk yang terhubung dengan masalah, siswa harus menggambar bentuk dan menunjukan yang tidak diketahui dari datanya.

\section{b. Tahap Merencanakan}

Pada tahap merencanakan, subjek menyajikan ide dalam bentuk verbal lisan dan tulisan untuk menghubungkan yang diketahui dan ditanyakan. Subjek menggunakan perbandingan tangen seperti tangen $=$ sisi depan berbanding sisi miring untuk menenitukan jarak puncak gedung dengan batas gedung yang sejajar dengan pandangan Amora. Perbandingan tangen juga digunakan untuk menenitukan jarak iklan dengan batas gedung yang sejajar dengan pandangan Amora. Subjek menyajikan strategi pemecahan masalah dalam bentuk verbal berupa lisan dan tulisan, yaitu tahapan-tahapan pemecahan masalah sesuai dengan ide yang dikemukakan. Pertama mencari nilai $x$ dengan menggunakan perbandingan tangen $60^{\circ}$ dan nilai $y$ dengan menggunakan perbandingan tangen $30^{\circ}$. Kemudian menenitukan jawaban akhir dengan mengurangi nilai $x$ dan $y$, serta menyatakan $x$ untuk prediksi lebar sungai pada tugas 2 .

MP menyajikan strategi dalam bentuk visual seperti menggunakan ilustrasi gambar dan segitiga yang telah dibuat pada tahap memahami, untuk membanitu memperjelas penjelasan strategi yang dipakai untuk menyelesaikan masalah pada soal. Selanjutnya, MP juga menyajikan strategi yang dijelaskan baik secara verbal dan visual. Menyatakan strategi dalam bentuk notasi formal, seperti tangen $30^{\circ}=\frac{x}{12}$ dan tangen $60^{\circ}=\frac{y}{12}$ pada tugas 1 dan perbandingan tangen tangen $30^{\circ}=\frac{x}{15}$ dan tangen $60^{\circ}=\frac{y}{15}$ pada tugas
2. Kemudian untuk soal nomor 2, MP menyatakan perbandingan tangen $30^{\circ}=\frac{x}{45}$.

Berdasarkan pembahasan di atas, terlihat bahwa subjek menyajikan ide-ide yang menyajikan hubungan informasi yang diketahui dan ditanyakan, sesuai dengan pendapat Polya (1973) bahwa hal yang penting dalam pemecahan masalah adalah memikirkan gagasan tentangen sebuah rencana. Pada bagian lain subjek menyajikan hubungan antar bagian dengan simbol tertentu seperti garis putus-putus pada ilustrasi gambar untuk menyatakan jarak tertentu dan membentuk bangun segitiga. Menggunakan garis batas untuk menunjukan bagian-bagian tertentu seperti untuk menunjukan jarak antara puncak gedung dan iklan, puncak gedung dan batas gedung. hal ini sesuai dengan pendapat Polya (1973) sebagai progres kerja, dapat menambahkan elemen baru ke informasi semula. Sebuah elemen yang diperkenalkan dengan harapan bahwa solusi ini akan disebut elemen tambahan.

c. Tahap Melaksanakan

Tahap melaksanakan, subjek melaksanakan rencana pemecahan masalah dengan representasi notasi formal meliputi penggunaan perbandingan tangen dan melakukan perhitungan bilangan. MP menyajikan hubungan antar bagian seperti memberikan simbol tertentu yaitu tangenda anak panak dan garis putus-putus pada ilustrasi gambar. Subjek Menginterpretasikan hasil penyelesaian yang diperoleh secara verbal seperti menyatakan dengan lisan ataupun tulisan alasan pada langkah-langkah penyelesaian.

Hal tersebut sesuai dengan yang di kemukakan oleh Polya (1973) bahwa pada tahapan ini dapatkah anda melihat dengan jelas bahwa langkah itu benar? Dapatkah anda membuktikan bahwa itu benar? Pada bagian ini rencana yang telah dibuat akan dilaksanakan. Dengan demikian pada tahapan ini subjek melakukan tahapan sesuai dengan yang dikemukanan oleh polya.

\section{d. Tahap Memeriksa}

Pada tahap memeriksa, Subjek memeriksa kembali penyelesaian, memastikan benar atau tidak nilai perbandingan tangen. Selain itu, subjek juga mengungkapkan benar tidaknya langkah penyelesaian melalui representasi formal seperti melakukan perhitungan bilangan yang dilakukan pada proses penyelesaian soal. Pemeriksaan dilakukan secara verbal karena perhitungan bilangan yang dilakukan tidak melibatkan bilangan yang rumit, sehingga tidak dilakukan pengecekan kembali seperti melakukan perkalian bersusun. Pemeriksaan subjek lakukan dengan mengecek hasil operasi langkah demi langkah apakah sudah benar ataukah belum. 
Berdasarkan pendapat yang dikemukakan oleh Polya (1973) bahwa pada tahapan ini bisakah anda memeriksa hasilnya? Bisakah anda memeriksa argumennya? Bisakah anda menurunkan hasilnya secara berbeda? Bisakah kamu melihatnya sekilas? Dapatkah anda menggunakan hasilnya, atau metode, untuk beberapa masalah lainnya. Selain itu Polya (dalam Mint, 2012: 197) menyatakan bahwa untuk melihat ke belakang adalah memeriksa solusi yang diperoleh dari menyaring masalah menggunakan strategi yang dipilih. Langkah dalam proses penyelesaian masalah ini mendorong siswa untuk merefleksikan strategi yang mereka pilih dan membuat generalisasi yang dapat diterapkan untuk masalah di masa depan.

\subsection{Proses Representasi Matematis Subjek Dengan Kecerdasan Visual Spasial (VP) Dalam Menyelesaikan Masalah Perbandingan Trigonometri Dalam Segitiga Siku-siku.}

a. Tahap Memahami

Pada tahap memahami, subjek menyajikan informasi yang diketahui dalam bentuk representasi verbal yaitu menyajikan dengan tulisan lisan maupun tulisan informasi yang diketahui. Penyajian informasi tersebut seperti sudut elevasi yang terbentuk pada pandangan Amora ke puncak gedung dan iklan pada gedung, serta jarak Amora dengan gedung. Selanjutnya, informasi yang ditanyakan yaitu, menenitukan jarak puncak gedung dengan iklan pada gedung. Menyajikan informasi yang diketahui dengan menggunakan notasi formal, seperti menggunakan A untuk Amora, B untuk puncak gedung, $C$ untuk batas gedung yang sejajar dengan pandangan Amora dan D untuk iklan.

Selanjutnya, subjek menyatakan $\mathrm{AB}$ untuk jarak pandang Amora ke puncak gedung, $A C$ untuk jarak Amora dengan gedung dan menyajikan sudut A dua untuk sudut pandang yang berbeda pada tugas 1. Selanjutnya, pada tugas 2 subjek menyatakan letak ahli bangunan terhadap batu B di seberang sungai yang membentuk sudut terhadap panjang sungai, jarak ahli bangunan berjalan ke titik C.

Subjek menyajikan informasi yang diketahui dan ditanyakan dalam bentuk notasi formal $\mathrm{AB}$ untuk jarak pandang ahli bangunan dengan batu B. Sudut A untuk sudut pandang ahli bangunan ke batu $\mathrm{B}$ dan $\mathrm{AC}$ untuk jarak ahli bangunan ke titik $\mathrm{C}$ yang sejajar dengan batu $\mathrm{B}$. $\mathrm{BC}$ untuk prediksi lebar sungai yang akan dihitung oleh ahli bangunan.

Pada tahapan ini subjek juga menyajikan informasi yang diketahui dan ditanyakan dalam bentuk visual, dengan menggambarkan ilustrasi gambar yang didalamnya langsung tergambarkan bentuk segitiga. Menyajikan informasi yang ditanyakan dalam bentuk notasi formal yaitu BD untuk jarak antara puncak gedung dengan iklan pada gedung pada tugas 1 , dan $\mathrm{BC}$ untuk prediksi lebar sungai pada tugas 2 .

Pada tahap memahami, subjek cenderung menggunakan ketiga representasi verbal, notasi formal dan visual dalam menyajikan informasi yang diketahui maupun ditanyakan dari soal. Subjek menggunakan representasi visual untuk membantu menyajikan informasi dari masalah matematika yang diselesaikan. Hal ini sesuai dengan yang dikemukakan oleh Polya (1973) jika ada bentuk yang terhubung dengan masalah, siswa harus menggambar bentuk dan menunjukan yang tidak diketahui dari datanya.

Dari pembahasan di atas terlihat bahwa subjek menyajikan informasi-informasi yang terdapat pada soal, hal ini sesuai dengan yang dikemukakan Polya (1973) pada tahap memahami yaitu siswa juga harus bisa menunjukan bagian utama dari masalah diketahui, data dan kondisinya.

\section{b. Tahap Merencanakan}

Pada tahap merencanakan, subjek menyajikan ide dalam bentuk verbal lisan dan tulisan untuk menghubungkan yang diketahui dan ditanyakan, mengemukakan alasan menggunakan perbandingan tangen dalam menyelesaikan soal. Selanjutnya, subjek menyatakan ide dalam bentuk visual dengan menggambarkan ilustrasi dari permasalahan. Dari ide yang dinyatakan maka dapat mengetahui bahwa perbandingan tangen dapat digunakan dalam menyelesaikan soal.

Subjek kemudian menyatakan ide yang telah dikemukakan di atas dalam bentuk notasi formal, seperti menyajikan perbandingan tangen dengan menggunakan notasi formal dari informasi yang diketahui dan ditanyakan. Dalam tahap merencanakan ini subjek menyajikan strategi dalam bentuk verbal, menjelaskan langkahlangkah menyelesaikan permasalahan pada soal dengan lisan maupun dengan tulisan dengan berpedoman pada ide yang telah dikemukakan.

Subjek menyajikan strategi dalam bentuk visual dengan membuat gambar segitiga yang diangkat dari gambar ilustrasi soal, untuk melakukan tahapan dalam menyelesaikan soal. selanjutnya, strategi yang telah disampaikan tadi, subjek menyatakan strategi penyelesaian masalah tersebut dengan menyajikan strategi yang telah dijelaskan tadi dalam bentuk notasi formal seperti perbandingan tangen sisi depan berbanding sisi miring adalah tangen $60^{\circ}=\frac{B C}{A D} \quad$ dan tangen $30^{\circ}=\frac{C D}{A D} . \quad$ Selanjutnya, $\quad$ menjelaskan strategi langkah pertama menenitukan panjang $\mathrm{BC}$ 
dengan menggunakan tangen $60^{\circ}=\frac{B C}{A D}$, selanjutnya menenitukan nilai $\mathrm{CD}$ dengan tangen $30^{\circ}=\frac{C D}{A D}$. Setelah menenitukan nilai $\mathrm{BC}$ dan $\mathrm{CD}$, menenitukan subjek nilai BD yaitu jarak antara puncak gedung dan iklan.

Berdasarkan pembahasan di atas, terlihat bahwa subjek menyajikan ide-ide yang menyajikan hubungan informasi yang diketahui dan ditanyakan, sesuai dengan pendapat Polya (1973) bahwa hal yang penting dalam pemecahan masalah adalah memikirkan gagasan tentangen sebuah rencana.

Pada bagian lain subjek menyajikan hubungan antar bagian dengan simbol tertentu seperti tangenda anak panak untuk menunjukan bagian-bagian tertentu seperti untuk menunjukan jarak antara puncak gedung dan iklan, puncak gedung dan batas gedung. hal ini sesuai dengan pendapat Polya (1973) sebagai progres kerja, dapat menambahkan elemen baru ke informasi semula. Sebuah elemen yang diperkenalkan dengan harapan bahwa solusi ini akan disebut elemen tambahan.

\section{c. Tahap Melaksanakan}

Pada tahap melaksanakan, subjek melaksanakan rencana pemecahan masalah dengan representasi notasi formal meliputi penggunaan perbandingan tangen dan melakukan perhitungan bilangan. Subjek menyajikan hubungan antar bagian seperti memberikan simbol tertentu yaitu tangenda anak panak dan garis putus-putus pada ilustrasi gambar. Subjek menginterpretasikan hasil penyelesaian yang diperoleh secara verbal seperti menyatakan dengan lisan ataupun tulisan alasan pada langkah-langkah penyelesaian. Pada tahap ini subjek lebih cenderung menggunakan notasi formal berupa notasi-notasi matematika untuk menyelesaikan soal.

Hal tersebut sesuai dengan yang dikemukakan oleh Polya (1973: 5) bahwa pada tahapan ini dapatkah anda melihat dengan jelas bahwa langkah itu benar? Dapatkah anda membuktikan bahwa itu benar? Pada bagian ini rencana yang telah dibuat, akan dilaksanakan. Dengan demikian pada tahapan ini subjek melakukan tahapan sesuai dengan yang dikemukanan oleh Polya.

\section{d. Tahap Memeriksa}

Pada tahap memeriksa, subjek memeriksa kembali penyelesaian, menghitung kembali operasi yang telah dilakukan dan mengungkapkan benar tidaknya langkah penyelesaian melalui representasi formal seperti melakukan perhitungan bilangan yang dilakukan pada proses penyelesaian soal. Gambar berikut ini menyajikan proses representasi subjek dalam menyelesaikan masalah tugas 1 dan 2 soal nomor 1. Pemeriksaan dilakukan secara verbal karena perhitungan bilangan yang dilakukan tidak melibatkan bilangan yang rumit, sehingga tidak dilakukan pengecekan kembali seperti melakukan perkalian bersusun.

Berdasarkan pendapat yang dikemukakan oleh Polya (1973) bahwa pada tahapan ini bisakah anda memeriksa hasilnya? Bisakah anda memeriksa argumennya? Bisakah anda menurunkan hasilnya secara berbeda? Bisakah kamu melihatnya sekilas? Dapatkah anda menggunakan hasilnya, atau metode, untuk beberapa masalah lainnya. Selain itu, Polya (dalam Mink, 2012: 197) menyatakan bahwa untuk melihat kembali adalah memeriksa solusi yang diperoleh dari menyaring masalah menggunakan strategi yang dipilih. Langkah dalam proses penyelesaian masalah ini mendorong siswa untuk merefleksikan strategi yang mereka pilih dan membuat generalisasi yang dapat diterapkan untuk masalah di masa depan.

\section{Kesimpulan}

Representasi matematis subjek dengan kecerdasan logis matematis menyatakan representasi matematis dalam bentuk verbal, notasi formal dan visual. Pada tahap memahami subjek menggabungkan ketiga bentuk representasi untuk menyatakan informasi yang diketahui maupun ditanyakan. Selanjutnya, pada tahap merencanakan subjek menggunakan representasi notasi formal untuk menjelaskan ide maupun strategi untuk menyelesaikan masalah matematika. Subjek menggunakan representasi notasi formal untuk menyelesaiakan permasalahan dan mengeceknya kembali dalam bentuk representasi verbal.

Representasi matematis subjek dengan kecerdasan linguistik menyatakan representasi matematis dengan menggabungkan representasi verbal dan visual. Subjek lebih menggunakan representasi verbal dalam bentuk tulisan untuk menyatakan informasi. Pada tahap merencanakan, subjek menjelsakan ide dan strategi yang akan digunakan dalam bentuk representasi verbal. Selanjunya, pada tahap menyelesaikan subjek menggunakan notasi formal dan menyatakan beberapa langkah dengan representasi verbal dalam tulisan. Pada tahap memeriksa kembali subjek menggunakan representasi verbal dalam bentuk lisan untuk menjelaskan kembali proses penyelesainnya. 


\section{Daftar Pustaka}

Ainsworth, Shaaron. 1999. The Functions of Multiple Representations. Computers \& Education 33 (1999) 131-152.

Amstrong, Thomas. 2009. Multiple Intelligences in The Clasroom. USA: ASCD

Anonim. 2014. NCTM Proses Strandart: Representation. https://mathequality.wordpress.com/2014/01/1 2/nctm-process-standard-representation/, , diakses pada tanggal 6 Februari 2020.

Cheung, Kwok-Cheung. 2009. Reforming Teaching and Learning Using Theory of Multiple Intellegences: The Macao Experiences. Australia: Business Media B. V.

Depdiknas. 2006. Panduan Penyusunan Kurikulum Tingkat Satuan Pendidikan. Jakarta: Badan Standar Nasional Pendidikan.

Gangi, S. 2011. Differentiating Instruction using Multiple Intelligences in the Elementary School Classroom: A Literature Review. A Research Paper University of Wisconsin-Stout.

Irvaniyah, I., Akbar R. O., 2014. Analisis Kecerdasan Logis Matematis dan Kecerdasan Linguistik Siswa Berdasarkan Jenis Kelamin (Studi Kasus Pada Siswa Kelas XI IPA MA Mafatihul Huda). EduMa Vol.3 No.1 Juli 2014, ISSN: 2086 - 3918.

Kartini. 2009. Peranan Representasi dalam Pembelajaran Matematika. Sminar Nasional
Matematika dan Pendidikan Matematika. ISBN: 978-979-16353-3-2.

Miles, M.B., Huberman, A.M., \& Saldana, J. 2014. Qualitative Data Analysis (Third Edition). London: SAGE Publication.

Mink, D. V. 2010. Strategies for Teaching Mathematics. Shell Education Publishing, Inc. Huntington Beach.

Moleong, J. L. 2000. Metodologi Penelitian Kualitatif Edisi Revisi. Bandung: PT Remaja Rosdakarya.

Mustangin, 2015. Representasi Konsep dan Peranannya dalam Pembelajaran Matematika di Sekolah. Jurnal Pendidikan Matematika. Volume 1. Nomor 1. ISSN: 2442-4668.

Polya, G. 1973. How ti Solve it. Princeton, New Jersey: Princeton University Press.

Rosidah, L. 2014. Peningkatan Kecerdasan Visual Spasial Anak Usia Dini melalui Permainan Maze. Jurnal Pendidikan Usia Dini. Volume 8 Edisi 2.

Wijaya, P. P. 2019. Analisis Data Kualitatif Sebuah Tinjauan Teori dan Praktik. Edisi Pertama, cetakan ke-1. ISBN: 978-623-901515-7-0.

Winarto, P. 2010. Maximing Your Talent (Menemukan \& Memakxsimalkan Potensi Diri Anda). Jakarta: libri, PT BPK Gunung Mulia.

Yaumi, M. 2015. Desain Strategi Pembelajaran untuk Mengembangkan Kecerdasan VerbalLingustik Peserta Didik. Auladuna. Vol.2, No.1. 